\title{
Alberta Piping Plover Recovery Plan 2002-2004
}
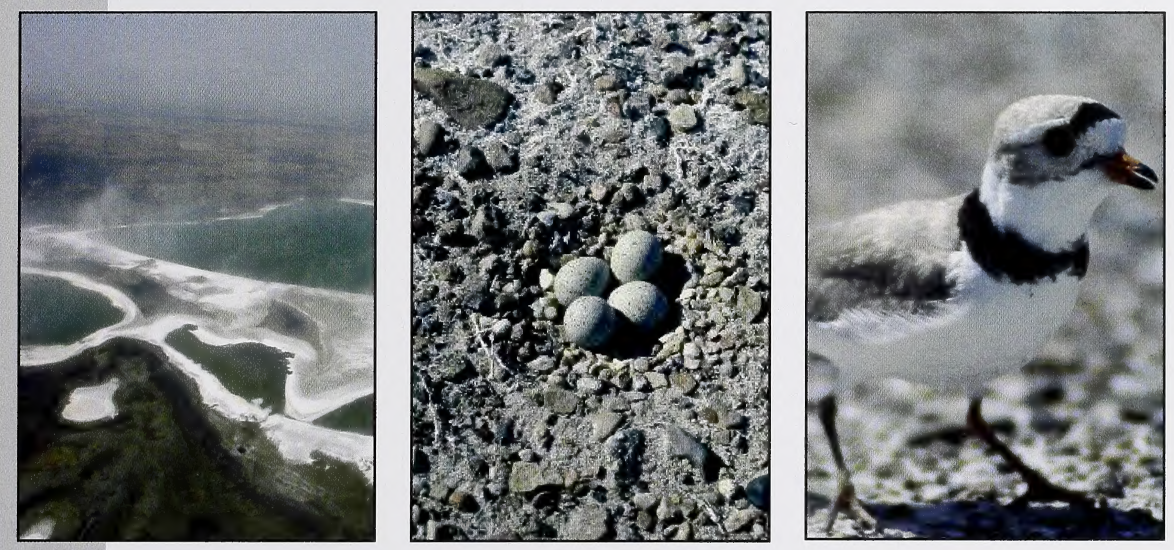

Alberta Species at Risk Recovery Plan No. 2

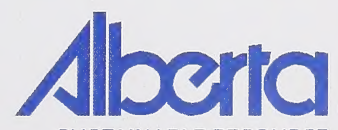

SUSTAINABLE RESOURCE DEVELOPMENT 


\section{Digitized by the Internet Archive}

in 2015 


\section{Alberta Piping Plover Recovery Plan 2002-2004}

Prepared by:

The Alberta Piping Plover Recovery Team

David R. C. Prescott (Team Leader), Alberta Fish and Wildlife Division Lance C. Engley, Alberta Conservation Association

J. Paul Goossen, Canadian Wildlife Service

Gerald A. Haekel, Alberta Public Lands Division

D. Edward Hofman, Alberta Fish and Wildlife Division

B. Craig Horner, Alberta Beef Producers

Dug Major, Special Areas Board

Dave Moore, Alberta Fish and Wildlife Division

Laurel L. Murphy, Nature Conservancy of Canada

Thomas S. Sadler, Ducks Unlimited Canada / Alberta North American

Waterfowl Management Plan

\section{April 2002}

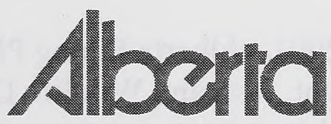

SUSTAINABLE RESOURCE

DEVELOPMENT 
Publication No.: I/084

ISBN: 0-7785-2317-9 (Printed Edition)

ISBN: 0-7785-2318-7 (On-line Edition)

ISSN: $1702-4897$ (Printed Edition)

ISSN: 1702-4900 (On-line Edition)

Cover photos: D. Prescott (left and centre), M. Piorecky (right)

For copies of this report, contact:

Information Centre - Publications

Alberta Environment / Alberta Sustainable Resource Development

Main Floor, Great West Life Building

9920 - 108 Street

Edmonton, Alberta, Canada T5K 2M4

Telephone: (780) 422-2079

\section{OR}

Information Service

Alberta Environment / Alberta Sustainable Resource Development

\#100, 3115 - 12 Street NE

Calgary, Alberta, Canada T2E 7J2

Telephone: (403) 297-6424

\section{OR}

Visit our web site at:

http://www3.gov.ab.ca/srd/fw/riskspecies/

This publication may be cited as:

Alberta Piping Plover Recovery Team. 2002. Alberta Piping Plover Recovery Plan, 2002-2004. Alberta Sustainable Resource Development, Fish and Wildlife Division, Alberta Species at Risk Recovery Plan No. 2. Edmonton, AB. 21 pp. 


\section{PREFACE}

Albertans are fortunate to share their province with a diverse variety of wild species. Populations of most species of plants and animals are healthy and secure. However, a small number of species are now imperilled because of human activities. We place a high value on these "species at risk" and need to work cooperatively with industry, conservation groups, landowners and other stakeholders to ensure these species and populations are restored or maintained for future generations.

One of the important components of Alberta's species at risk conservation program is the development and implementation of recovery plans for some species at risk. Alberta's commitment to the Accord for the Protection of Species at Risk, to the National Framework for the Conservation of Species at Risk, and to requirements established under Alberta's Wildlife Act, means that recovery plans will be completed for Alberta species that are designated as Threatened or Endangered. The overall goal of the recovery program is to restore species identified as Threatened or Endangered to viable, naturally self-sustaining populations within Alberta.

Alberta species at risk recovery plans are prepared under the supervision of the Alberta Fish and Wildlife Division. These recovery plans are prepared by recovery teams composed of a variety of stakeholders including government agencies, conservation organizations, industry, landowners, resource users, universities and others. Membership is by invitation from the Director of Wildlife Management in the Department of Sustainable Resource Development and includes representation from the diversity of interests unique to each species and circumstance. Preparation of these recovery plans will include an opportunity for other interested parties and individuals to comment on the plans for species recovery. Conservation and management of these species continues during preparation of the recovery plan.

Recovery plans are a comprehensive compilation of goals, objectives, strategies and actions, both short- and long-term, required for recovery of the particular Threatened or Endangered species. These plans are provided by the recovery team as advice to the Minister responsible for fish and wildlife management (the Minister) and to all Albertans. Completion of recovery plans includes a review and recommendation to the Minister from the Alberta Endangered Species Conservation Committee. Plans accepted and approved for implementation by the Minister are published as part of the recovery plan report series. Approved plans are a summary of the department's commitment to coordinate and implement conservation actions necessary to restore and/or maintain these species.

Recovery plans are "living" documents and are revised as conditions change or circumstances warrant. Each approved plan includes a process for plan review and for monitoring the results of implementation. Implementation will be subject to the identification of sufficient resources, from within and from outside government, to do the job that is required, while respecting overall program priorities of the Alberta Government. 


\section{TABLE OF CONTENTS}

PREFACE

ACKNOWLEDGEMENTS

EXECUTIVE SUMMARY

vi

1.0 INTRODUCTION

1.1 Ministerial Conservation Action Statement

1.2 Recovery Team

2.0 SPECIES BIOLOGY

2.1 Breeding Biology 2

2.2 Population Distribution and Trends in Alberta 3

3.0 LIMITING FACTORS 3

3.1 Predation 3

3.2 Livestock Grazing 4

3.3 Human Recreation/Disturbance 4

3.4 Vegetation Encroachment 5

3.5 Industrial Development 5

3.6 Water Management Activities 5

3.7 Other Factors 5

4.0 RECOVERY STRATEGY 6

4.1 Guiding Principles 6

4.2 Recovery Goals 6

4.3 Strategy for Recovery 7

5.0 ACTION PLAN FOR RECOVERY 8

5.1 Plan Management and Administration 8

$\begin{array}{ll}5.2 \text { Habitat Protection and Management___ } & 8\end{array}$

5.3 Productivity Enhancement __ 8

$\begin{array}{lr}5.4 \text { Information and Education } & 9\end{array}$

5.5 Research _ 9

5.6 Resourcing __ 9

6.0 IMPLEMENTATION SCHEDULE AND COSTS

7.0 REFERENCES _ 11

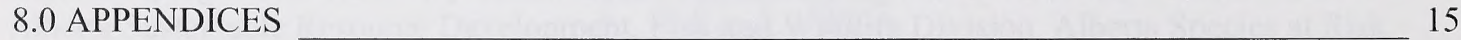




\section{ACKNOWLEDGEMENTS}

The members of the Alberta Piping Plover Recovery Team thank their respective organizations for providing in-kind support for the preparation of this plan. We also thank Mark Piorecky for compiling much of the information contained herein, and for preparing drafts for review by the team. The contribution of Isabelle Michaud, a former team member from the Alberta Conservation Association, is gratefully acknowledged. Many of the ideas that are contained in this plan arose from discussions with members of the former Ad Hoc Piping Plover Committee that are not part of the current recovery team. These include Ron Bjorge and Steve Brechtel (Alberta Fish and Wildlife Division), Ernie Ewaschuk (currently Land Stewardship Centre of Canada), Brian Ilnicki (Ducks Unlimited Canada), Russ Wells (Alberta Resource Data Division) and Andy Murphy (currently Alberta Conservation Association).

Funding from the Species at Risk Program of Alberta Sustainable Resource Development supported the preparation of the Alberta Piping Plover Recovery Plan, 2002-2004. 


\section{EXECUTIVE SUMMARY}

The piping plover (Charadrius melodus) is a small shorebird that breeds on sand or gravel beaches on the Atlantic coast, Great Lakes and Great Plains. Birds spend the winter along the southeastern Atlantic seaboard and the coast of the Gulf of Mexico, including some Caribbean islands. Less than 6000 individuals occur within the North American range, with approximately one third of these breeding in Canada. The species' range and population size has declined in recent decades, and the piping plover is listed as an Endangered species in most parts of its range, including in Canada by the Committee on the Status of Endangered Wildlife in Canada (COSEWIC).

In Alberta, the piping plover occurs on shorelines of saline lakes in the southeastern and east-central parts of the province. The species has been reported on 79 lakes in the province, with confirmed nesting occurring on 46 lakes. Habitat suitability varies spatially and temporally in the province, and no more than 31 lakes are known to have been occupied in any given year. Four major surveys have been conducted over the past 15 years, with a maximum of 276 individuals being counted in 1996. The third International Piping Plover Census in 2001 located 150 individuals on 23 lakes. This represents a $47.9 \%$ decline in numbers from 1986 , and $45.7 \%$ since 1996 . Predation is the main factor limiting population size in Alberta (up to two-thirds of nesting attempts fail due to predators), although vegetation encroachment, cattle grazing, recreational use, industrial development and water management also pose threats to breeding populations.

In February 2000, the piping plover was listed as Endangered in Alberta, because of low population size $(<250)$, threats to habitat, and an inability of existing management to increase population levels. Along with this listing, the Minister responsible for wildlife (now Sustainable Resource Development) issued a Conservation Action Statement that formally initiated recovery actions in the province. This included the formation of a multi-stakeholder recovery team that would advise the Minister on all matters relating to piping plover conservation in the province and produce a recovery plan within 24 months of listing. The plan was to emphasize that the loss of habitat and nests was unacceptable, and that management actions should ensure the protection of breeding sites through habitat conservation initiatives. The Alberta Piping Plover Recovery Plan, 2002-2004 was produced to embrace the objectives of the Ministerial Conservation Action Statement.

This recovery plan is guided by the following principles: (1) the recovery of piping plovers in Alberta is both achievable and desirable; (2) a loss of habitat and individuals is unacceptable; (3) a cooperative approach with landowners, industry and other agencies is essential; (4) management actions will employ tools resulting in the most immediate benefit to piping plovers and will be based on the best information available; (5) landowners will not be affected by the costs associated with recovery measures; (6) activities will be restricted to a small number of effective and achievable actions; (7) recovery actions will embrace an ecosystem (holistic) approach to management; (8) predator management activities will be accomplished through passive means; and (9) the recovery process will be guided by the concept of adaptive management.

Recovery goals for Alberta are based on population and productivity targets contained in the Canadian Piping Plover Recovery Plan, and on the directives of the Ministerial Conservation Action Statement. These goals are: 
(1) To achieve a well distributed long-term average population of 300 individual piping plovers, within their home range in Alberta;

(2) To ensure no net loss of breeding habitat quantity or quality (both breeding and feeding) due to human influences; and

(3) To employ all management techniques possible to achieve a median fledging rate of greater than 1.25 chicks/pair/year in the province.

This recovery plan will serve for an initial period of three years (2002-2004), and consists of six strategic areas, which will be pursued concurrently during this period: (1) plan management and administration; (2) habitat protection and management; (3) productivity enhancement; (4) information and education; (5) research; and (6) resourcing. A series of specific actions in each of these areas are detailed, along with anticipated costs and lead agencies. A major element of the recovery effort involves the preparation of management plans for at least 25 of the key breeding lakes in the province. These lake management plans will include all available information on piping plover populations and the location of breeding habitats on each lake, and will detail specific recovery actions to be implemented at each site.

The overall cost of the actions detailed in the recovery plan is $\$ 586,000$ over three years, including both cash and 'in-kind' support. A variety of agencies will be invited to participate in the funding and implementation of recovery initiatives. 


\subsection{INTRODUCTION}

\section{$\underline{1.1 \text { Ministerial Conservation Action Statement }}$}

In February 2000, the Minister responsible for wildlife (now Sustainable Resource Development), on recommendation from the Endangered Species Conservation Committee (ESCC), approved the up-listing of the piping plover from Threatened to Endangered in Schedule 6 of the Wildlife Regulation (AR 143/97). The status revision was based on Alberta's very small population (less than 250), persistent threats to habitat, and an inability of recent management actions to increase population levels. The action statement specified that a recovery plan would be prepared within 24 months, that all those with a stake in piping plover issues should be invited to participate in recovery planning, and that sufficient new resources should be made available to support essential conservation actions. Furthermore, the action statement advised that the loss of plover nests is unacceptable, and that management actions should ensure the protection of nests (and associated habitats) through direct contact with landowner/disposition holders, to facilitate voluntary conservation and/or the negotiation of cooperative management strategies. The Alberta Piping Plover Recovery Plan will be constructed to embrace the directives of the ministerial conservation action statement.

\subsection{Recovery Team}

The Alberta Piping Plover Recovery Team has been initiated by the Minister of Sustainable Resource Development, and receives operational guidance and approval from the Director of Fisheries and Wildlife Management. The team's primary responsibility is to facilitate and coordinate the conservation and recovery of this species in Alberta. It provides expert advise to the Minister (or his delegate) on all matters relating to the management of piping plovers in Alberta. The team is also responsible for writing, updating and guiding the implementation of the provincial recovery plan, and for providing input to the Prairie Piping Plover Recovery Team on matters relating to piping plover management in Alberta. The team does not normally implement the planned actions directly, although team members and the organizations they represent will participate in many of the planned activities. The team will encourage and facilitate the involvement of all interested parties in the recovery of piping plovers in the province when possible, and will periodically report on the progress of the recovery program.

Because of the multi-stakeholder nature of recovery issues, team membership will remain dynamic and strive for the best representation of all affected parties. The team will meet at least twice annually and currently consists of the following members: Alberta Beef Producers, Alberta Conservation Association, Fish and Wildlife Division and Public Lands Division (Alberta Sustainable Resource Development), Canadian Wildlife Service, Ducks Unlimited Canada / Alberta North American Waterfowl Management Plan, Nature Conservancy of Canada, and the Special Areas Board. 


\subsection{SPECIES BIOLOGY}

\subsection{Breeding Biology}

The piping plover (Charadrius melodus) is a small, thrush-sized shorebird characterized by its unique dry-sand colouration, high pitched 'piping' call, and habit of breeding on open sand or gravel beaches (Goossen et al. 2002). Three distinct breeding populations are recognized: the Atlantic coast (C. m. melodus), Great Lakes, and Great Plains (C. m. circumcinctus) populations. Birds breeding on the Atlantic coast tend to winter in coastal areas of the southeastern United States (Virginia to Florida), whereas the two inland-breeding populations generally winter from Florida to northern Mexico (Haig 1992). Band returns indicate that many Alberta birds winter near the Texas/Mexico border (Prescott unpubl. data). Fewer than 6000 individuals exist continent wide with approximately one third of these breeding in Canada (Plissner and Haig 1997). The population size and range of piping plovers have contracted in North America over the past few decades. The species has disappeared as a breeding bird from Illinois, Indiana, Ohio, Pennsylvania and New Hampshire, and populations have dropped to extremely low levels in Ontario and Iowa (Haig 1992, Goossen et al. 2000). The piping plover is now listed as Endangered in most jurisdictions where it occurs, including Alberta (Prescott 1997) and in Canada as a whole (COSEWIC 2001).

In Alberta, piping plovers arrive on their breeding grounds in late April (Pinel et al. 1991, Heckbert 1994, Heckbert and Cantelon 1996). Males establish a territory and attract a mate with a combination of aerial and ground displays. Clutches usually contain four eggs (Whyte 1985, Haig 1992). The latest clutch initiation for Alberta is recorded as 6 to 10 July (Alberta Fish and Wildlife 1991). Incubation of eggs is shared by both sexes and lasts 26 to 28 days (Haig 1992). Young leave the nest within several hours of hatching (Haig 1992), and are capable of sustained flight at about 28 days of age (Cairns 1982, Whyte 1985, Prindiville Gaines and Ryan 1988). Most birds leave the Canadian prairies for wintering grounds by the end of the first week in August (Wershler and Wallis 1987).

Reproductive success of piping plovers is highly variable between lakes and among years (Goossen 1994). Females are capable of breeding at one year of age and will renest if the eggs are destroyed, but have only been known to produce one brood per year (Haig and Oring 1988a, Bottitta et al. 1997). Fledging success of 0.50 young/pair has been calculated in Alberta (Richardson 1999), which is less than values calculated over the Great Plains as a whole (0.86 young/pair; Ryan et al. 1993). Various models have estimated that minimum productivity levels between 1.13-1.7 young/pair are required to maintain stable populations on the Great Plains (Ryan et al. 1993, Plissner and Haig 2000). The most recent model suggests a median productivity of 1.25 chicks/pair/year is required (M. A. Larson, pers. comm.).

Estimates of fidelity of individually marked adults to breeding areas on the Great Plains range between $42 \%$ and $71 \%$ for adults, but typically less than $14 \%$ for juveniles (Whyte 1985, Haig and Oring 1988a,b, Goossen 1989, Root et al. 1992). Haig and Oring (1988b) demonstrated that fidelity is highest in areas with large amounts of suitable breeding habitat. Birds have been known to disperse up to $1500 \mathrm{~km}$ from one breeding season to the next (Haig and Oring 1988b). 


\subsection{Population Distribution and Trends in Alberta}

In Alberta, piping plover distribution is widespread but sparse, and limited primarily to saline lakes across the aspen parkland, northern fescue grassland, and mixedgrass regions of southeastern and east-central Alberta. Piping plover surveys began in earnest in 1986. Wershler and Wallis (1987) identified potential breeding sites from aerial photographs, and located plovers on 28 water bodies. Eleven of these sites were previously unknown breeding locations. In 1991, the first International Piping Plover Census was conducted across North America. In Alberta, 48 water bodies were surveyed and 180 plovers were recorded (Hofman 1994). Several new breeding sites were discovered during the next few years, and the next international census in 1996 was extended to include 103 lakes, with 276 plovers being found (Bjorge 1997). In 2001, 115 lakes were surveyed on the ground and an additional 11 lakes surveyed on previous censuses were checked from the air and assumed to be unpopulated because of a lack of suitable habitat (Prescott 2001a). A total of 150 birds were recorded, including 27 plovers on four lakes that were surveyed for the first time. Populations on many of the 'traditional' key lakes, however, were well down from previous years, even though habitat conditions were reasonable (Prescott 2001b). Overall, the provincial population in 2001 had declined by $47.9 \%$ since 1986, and $45.7 \%$ since 1996 (Prescott 2001b). The magnitude of these declines is undoubtedly underestimated, as the effort expended on surveys, and the skill level of observers, has increased with each survey effort (Prescott 2001b).

Overall, piping plovers have occurred on at least 79 lakes in the province, with at least 69 of these being occupied during the breeding season (Appendix 1 and 2). Breeding has been confirmed on 46 lakes (Appendix 1). However, changing habitat conditions mean that not all lakes will support breeding pairs in any given year. Over the four major surveys conducted since 1986, the number of lakes supporting breeding birds has varied between 23 and 31, with only six lakes supporting birds on all four censuses (Prescott 2001b).

\subsection{LIMITING FACTORS}

Limiting factors are considered to be those conditions that degrade habitat suitability, reduce survivorship of young or adults, or decrease nesting success of adults once they are established at a site (Prescott 1997). From a management standpoint, an understanding of these factors is important because they identify mechanisms through which plover recovery may be achieved. The limiting factors discussed below have been identified as affecting Alberta populations of piping plovers (Wershler 1992, Prescott 1997, Goossen et al. 2002). Management actions that have been used to mitigate some of these factors are also listed. However, not all actions may be applicable or practical for piping plover recovery in Alberta.

\section{$\underline{3.1 \text { Predation }}$}

Predation on eggs and chicks is the greatest source of reproductive failure in piping plovers on the Great Plains. Richardson (1999) found that $64 \%$ of nesting attempts in Alberta failed because of depredation. Instances of predation are rarely observed, and the types of predators are poorly documented (Haig et al. 1988). American crows (Heckbert 1994) and gulls (Heckbert 
and Cantelon 1996) are most often implicated in Alberta. However, black-billed magpies, American ravens, great horned owls, northern harriers, coyotes, raccoons, weasels and domestic dogs have also been observed, or suspected of, preying upon eggs or young (Whyte 1985, Espie et al. 1992, Heckbert 1994). Although the loss of eggs and chicks to predators is a natural process, there is evidence that urbanization and recreational use of beaches have increased populations of gulls, foxes and skunks in some areas (Haig 1985). Little is known about adult mortality. However, mink, red fox, peregrine falcons and merlins are known to be responsible for adult predation (Haig 1992, Michaud and Prescott 1999, Nova Scotia DNR unpubl. data, W. Harris pers. comm.). Management tools employed to decrease plover predation include predator removal, removal of stick nests, electric fencing and erecting predator exclosures around nests. A predator exclosure project initiated in Alberta in 1996 showed that fledging success rates of exclosed nests were more than double those of unexclosed nests (Richardson 1999). The project has continued to operate on key plover lakes since that time.

\section{$\underline{3.2 \text { Livestock Grazing }}$}

Livestock can disturb nesting substrates, interfere with normal nesting behaviour by established birds, and directly destroy eggs. In addition, young plovers may fall into deep hoof prints and be unable to escape (Wershler and Wallis 1987, Hofman 1992). Furthermore, the construction of dugouts adjacent to shorelines can foul nesting beaches, change basin hydrology and accelerate vegetative encroachment (Heckbert 1994). Cattle impacts on shorelines generally increase with decreasing salinity (Wershler and Wallis 1987, Harris 1992). Although most plover habitat in the Great Plains occurs on alkaline lakes, the impacts of grazing on plovers in this area can be substantial. Studies have shown nesting success to be lower on territories with evidence of cattle (Prindiville Gaines and Ryan 1988, Hofman 1992). Livestock activity has been documented on a number of lakes in Alberta (Wershler 1992, Heckbert and Cantelon 1996). During the 2001 International Piping Plover Census, grazing was assessed to be a potential threat on $66.3 \%$ of all lakes surveyed and 69.6\% of lakes containing plovers (Prescott 2001b). These numbers are relatively consistent with those reported in 1991 (66.7\%; recalculated from Hofman 1994) and 1996 (82.6\%; Bjorge and Murphy In prep.). Despite the potentially negative effects of livestock on plover populations, impacts can be reduced by effective and inexpensive measures such as fencing, establishment of new water sources and deferred grazing practices.

\subsection{Human Recreation/Disturbance}

Human disturbance occurs through motorized off-road travel (all-terrain vehicles), or by nonmotorized, recreational use of beaches. Such disturbances can affect plovers by directly destroying nests and eggs, or by indirectly interfering with territory establishment and other reproductive behaviours (Cairns 1982, Flemming et al. 1988, Haig et al. 1988). Although most plovers in Alberta nest on lakes that are unattractive for recreation (Weseloh and Weseloh 1983), motorized vehicles (Wershler and Wallis 1987, Wershler 1992) and recreational use of beaches (Wershler 1992, Heckbert 1994, Heckbert and Cantelon 1996) have been documented on a number of plover lakes in Alberta. During the 2001 International Piping Plover Census, motorized vehicles were assessed to be a threat on $18.6 \%$ of all lakes surveyed and $34.8 \%$ of lakes supporting piping plovers. Similarly, recreational/residential use was determined to have an impact on $12.8 \%$ of lakes surveyed and $26.1 \%$ of lakes supporting plovers (Prescott $2001 \mathrm{~b}$ ). 
Management activities aimed at reducing human disturbance include signage, symbolic fencing and contact with recreation and user groups.

\subsection{Vegetation Encroachment}

The quality and quantity of piping plover habitat is in constant fluctuation owing to ever changing climate and weather conditions (Goossen et al. 2002). The presence of suitable nesting habitat for piping plovers requires alternating periods of high and low water to remove vegetation and expose gravel substrates on nesting beaches (Prescott 1997). Although this process is a natural occurrence, anthropogenic influences (i.e. grazing and water management) can also affect the rate and extent of encroachment by vegetation on shorelines. During the 2001 International Piping Plover Census, vegetation encroachment was identified as a potential threat on over $41 \%$ of all lakes surveyed and on over $52 \%$ of lakes with plovers (Prescott $2001 \mathrm{~b}$ ). Management tools used to minimize vegetation encroachment include burning, herbicide use, mechanical ground disturbance and fall/winter grazing.

\subsection{Industrial Development}

Wershler (1992) suggested that the exploration and extraction of fossil fuels around plover breeding sites could pollute water and shorelines, deplete water levels or interfere with ground water dynamics, and eliminate surrounding vegetation. The direct impacts of oil and gas development on plover habitat are not well documented, but activity has been reported in close proximity to several breeding sites in Alberta. During the 2001 International Piping Plover Census, industrial activity along with petroleum exploration/extraction were assessed to be a potential threat on $10.5 \%$ of all lakes surveyed and $13 \%$ of lakes supporting plovers in Alberta (Prescott 2001b).

\subsection{Water Management Activities}

Concern has been expressed over projects that stabilize water levels to enhance recreational opportunities. These projects remove the natural fluctuation of water levels required to provide plover nesting habitat. Such projects are underway at Buffalo Lake, have been proposed for Little Fish Lake (Goossen 1994), and may limit plover habitat on Lake Newell and Keho Lake (G. Erickson pers. comm.). The practice of allowing water levels on reservoirs to rise after plovers have started nesting is also particularly destructive (Espie et al. 1992, Jung et al. 1998). Water levels then typically fall throughout the summer as irrigation and hydroelectric demands are met. In Alberta, water level fluctuations due to irrigation practices are known to have affected plovers breeding on Keho Lake (Wershler 1992). In 2001, water management activities were identified as potential threats on $8.1 \%$ of all lakes surveyed for the International Piping Plover Census and $8.7 \%$ of lakes supporting plovers (Prescott 2001b).

\section{$\underline{3.7 \text { Other Factors }}$}

A variety of other factors can affect piping plover populations. Many of these factors, however, are either unpredictable or impossible to control or mitigate from an Alberta perspective. For example, severe storms may cause nest loss and reduced fledging success (Murphy et al. 1995). 
On "Piper" Lake', four of six nests were abandoned in 1999 after being flooded in a single storm event (Michaud and Prescott 1999). In addition, because piping plovers spend only $30 \%$ of their annual cycle on the breeding grounds, most adult bird mortalities likely occur in wintering areas or during migration (Root et al. 1992). Events occurring outside of Alberta, therefore, have the potential for major impacts on local piping plover populations.

\subsection{RECOVERY STRATEGY}

\subsection{Guiding Principles}

It is important to acknowledge that there are a number of factors affecting recovery that are beyond the control of the Alberta Piping Plover Recovery Team or this recovery plan. For example, the piping plover's migratory nature and international life cycle requirements mean that the policies and actions of numerous governments and industries will to some extent affect the success of our recovery efforts. Regardless, it is the recovery team's belief, and our primary guiding principle, that recovery of the piping plover is both possible and desirable.

The recovery and management of piping plovers in Alberta will be guided by the following additional principles:

- The loss of habitat and individuals is unacceptable.

- A cooperative approach with landowners, industry and other agencies is essential. This includes shared stewardship, compatible land use and local commitment to management initiatives.

- Management actions will employ tools resulting in the most immediate benefit to piping plovers, and will be based on the best information available. However, implementation will not be delayed because of a lack of specific supporting information.

- Landowners will not be affected by the costs associated with maintaining or enhancing piping plover habitat, or other recovery measures.

- Activities will be restricted to a small number of effective and achievable actions.

- Recovery actions will embrace an ecosystem (holistic) approach to management.

- Predator management activities will be accomplished through passive means (deterrence).

- The recovery process will be guided by the concept of adaptive management, wherein specific actions are revisited and altered to ultimately improve the outcome.

\subsection{Recovery Goals}

The Alberta recovery goals are based on population and productivity targets established by the National Recovery Plan for Piping Plover (Goossen et al. 2002) and the directives of the Ministerial Conservation Action Statement. These goals are:

1. To achieve a well-distributed, long-term average population of 300 individual piping plovers within their home range in Alberta.

\footnotetext{
'Names of lakes not listed by the Canadian Permanent Committee on Geographic Names (1988) are considered to be unofficial names, and are enclosed in parentheses throughout this report.
} 
2. To ensure no net loss of breeding habitat quantity or quality (both breeding and feeding) due to human influences.

3. To employ all management techniques possible to achieve a median fledging rate of greater than 1.25 chicks/pair/year in the province.

\subsection{Strategy for Recovery}

The Alberta Piping Plover Recovery Plan will serve for an initial period of three years (20022004), and consists of six strategic areas, which will be pursued concurrently:

- Plan Management and Administration: Includes operation of recovery team, coordination/implementation of recovery plan, recovery plan evaluation/review and data management.

- Habitat Protection and Management: May include cooperative stewardship, habitat securement, water management, vegetation control and grazing system management.

- Productivity Enhancement: Includes all management techniques aimed at increasing the reproductive success of breeding piping plovers.

- Information and Education: Includes actions required to promote awareness and communication between the agencies responsible for the execution of the recovery plan and the stakeholders affected by piping plover issues.

- Research: Includes all actions related to population monitoring and evaluation of management actions in Alberta.

- Resourcing: Includes securing continued and future government, non-government and industry support for recovery efforts in the province. 


\subsection{ACTION PLAN FOR RECOVERY}

The recovery actions outlined below form the basis of a three-year plan aimed at achieving the three provincial recovery goals for Alberta. Site-specific actions for all key lakes will be developed further in individual lake management plans (see action 5.2.4).

\subsection{Plan Management and Administration}

5.1.1 Convene the Alberta Piping Plover Recovery Team a minimum of twice annually and circulate results of these meetings to interested persons.

5.1.2 Monitor and assess the progress of recovery plan actions, and develop new recovery strategies and actions when needed.

5.1.3 Co-ordinate at least one training session per year in two or more Fish and Wildlife regions. Sessions will be open to all interested stakeholders and will prepare individuals for participation in annual population monitoring surveys and other field initiatives.

5.1.4 Recruit and train additional field staff to maintain and conduct annual field programs.

5.1.5 Liase with the Prairie Piping Plover Recovery Team and other provincial, multiprovincial or international conservation initiatives and municipal governments to ensure continuity and flow of information between agencies.

5.1.6 Enter accumulated plover data into the Biodiversity/Species Observation Database (BSOD) and other centralized databases following each field season.

\section{$\underline{5.2 \text { Habitat Protection and Management }}$}

5.2.1 Identify quarter sections on all lakes that have plovers or have had plovers in the past.

5.2.2 Make applications to Public Lands Division to apply protective notations, consultative notations or other protective designations to all quarter sections occurring on provincial public land.

5.2.3 Establish the recovery team as a key contact in the Alberta Water Licensing referral system (and other government referral systems), for consultation regarding activities that affect the habitat and natural hydrology of plover-inhabited lakes.

5.2.4 Create at least 25 lake management plans over the next two years. The plans will detail specific management actions required to assist plover recovery on key breeding lakes in the province (as identified by the recovery team). See Appendix 3 for a sample lake management plan.

5.2.5 Hire personnel to negotiate cooperative management options detailed in lake management plans with landowners.

5.2.6 Implement recovery actions in lake management plans, with the lead organisation to be determined on a case-by-case basis and organisation availability.

\section{$\underline{5.3 \text { Productivity Enhancement }}$}

5.3.1 Expand the predator exclosure project to include as many lakes as available personnel hours and funding will allow. 
5.3.2 Train permanent and field staff in the use of predator exclosures and the collection of productivity data.

5.3.3 Compile and review existing literature on the effectiveness of various predator deterrence techniques as a management tool for increasing plover productivity.

5.3.4 Expand the use of specific predator deterrence measures such as removal of stick nests of avian predators (crows, raptors) to increase plover survivorship.

\section{$\underline{5.4 \text { Information and Education }}$}

5.4.1 Perform presentations on plover-related issues to technical and non-technical audiences.

5.4.2 Produce and distribute a piping plover information package for landowners affected by plover issues. This information should be produced in consultation and partnership with stakeholder organizations.

5.4.3 Explore methods of informing and educating industrial developers that may affect piping plover recovery (e.g., seismic industry).

5.4.4 Produce annual reports including work plan alterations, progress updates, and evaluation and revision of goals and objectives.

\section{$\underline{5.5 \text { Research }}$}

5.5.1 Conduct annual adult and brood surveys on a core of at least 25 primary lakes each year depending on water cycles and habitat availability.

5.5.2 Spend three days per year performing aerial surveys, in an attempt to identify previously unknown plover habitat and to assess the current condition of known plover lakes before conducting annual population surveys.

5.5.3 Continue with opportunistic banding, capture of banded adults and compilation of observations of banded birds.

5.5.4 Compile existing information on piping plover populations and productivity on individual lakes, to provide a baseline against which to evaluate future management actions.

\subsection{Resourcing}

5.6.1 Establish annual work plans and determine funding levels required to carry out recovery actions.

5.6.2 Approach government, non-government and industry partners to participate in or fund piping plover recovery initiatives, both locally and provincially. 


\subsection{IMPLEMENTATION SCHEDULE AND COSTS}

The following schedule outlines those activities identified as being important to piping plover recovery by the Alberta Piping Plover Recovery Team, and their associated costs (cash and 'inkind'). It is anticipated that a variety of agencies will participate in the funding and implementation of these activities.

\begin{tabular}{|c|c|c|c|c|c|c|}
\hline \multirow[b]{2}{*}{ Task No. } & \multirow[b]{2}{*}{ Activity } & \multirow[b]{2}{*}{ Lead Agency } & \multicolumn{3}{|c|}{ Cost Estimate (\$000's/Year) } & \multirow[b]{2}{*}{ TOTAL } \\
\hline & & & $2002-03$ & 2003-04 & 2004-05 & \\
\hline 5.1 & Plan Management/Administration & & & & & \\
\hline $5.1 .1-5.1 .2$ & Recovery Coordination ${ }^{1}$ & SRD & 18 & 18 & 18 & 54 \\
\hline $5.1 .3-5.1 .4$ & Training of Staff & SRD & 2 & 2 & 2 & 6 \\
\hline 5.1 .5 & National/Interagency Meetings & SRD & 1.5 & 1.5 & 1.5 & 4.5 \\
\hline \multirow[t]{2}{*}{5.1 .6} & \multirow[t]{2}{*}{ Database Management } & \multirow[t]{2}{*}{ SRD } & 3 & 0.5 & 0.5 & 4 \\
\hline & & & 24.5 & 22 & 22 & 68.5 \\
\hline 5.2 & Habitat Management & & & & & \\
\hline 5.2 .1 & Identify Areas for Protective Notation & $\mathrm{SRD} / \mathrm{CWS}$ & 10 & & & 10 \\
\hline 5.2 .2 & Application for Protective Notation & SRD & 10.5 & 3.5 & & 14 \\
\hline 5.2 .3 & Liaison with Water Referral System & SRD & $*$ & $*$ & * & \\
\hline 5.2 .4 & Creation of Lake Management Plans & SRD & 25 & 5 & & 30 \\
\hline 5.2 .5 & Landowner Liaison & Various & 25 & 25 & 25 & 75 \\
\hline \multirow[t]{2}{*}{5.2 .6} & \multirow[t]{2}{*}{ Execution of Lake Management Plans } & \multirow[t]{2}{*}{ Various } & 40 & 60 & 60 & 160 \\
\hline & & & 110.5 & 93.5 & 85 & 289 \\
\hline 5.3 & Productivity Enhancement & & & & & \\
\hline \multirow{4}{*}{$\begin{array}{l}5.3 .1-5.3 .2 \\
5.3 .3 \\
5.3 .4\end{array}$} & \multirow{4}{*}{$\begin{array}{l}\text { Predator Exclosure Project } \\
\text { Review of predator management } \\
\text { Stick-nest Removal }\end{array}$} & \multirow{4}{*}{$\begin{array}{l}\text { ACA } \\
\text { SRD } \\
\text { ACA }\end{array}$} & 30 & 30 & 30 & 90 \\
\hline & & & 4 & & & 4 \\
\hline & & & 2 & & 2 & 4 \\
\hline & & & 36 & 30 & 32 & 98 \\
\hline 5.4 & \multicolumn{2}{|l|}{ Information $/$ Education } & & & & \\
\hline \multirow{4}{*}{$\begin{array}{l}5.4 .1 \\
5.4 .2-5.4 .3 \\
5.4 .4\end{array}$} & \multirow{4}{*}{$\begin{array}{l}\text { Presentations } \\
\text { Landowner Information Package } \\
\text { Annual Report }\end{array}$} & \multirow{4}{*}{$\begin{array}{l}\text { Various } \\
\text { Various } \\
\text { SRD }\end{array}$} & * & * & * & \\
\hline & & & 8 & . & & 8 \\
\hline & & & 3 & 3 & 3 & 9 \\
\hline & & & 11 & 3 & 3 & 17 \\
\hline 5.5 & Research & & & & & \\
\hline \multirow{5}{*}{\begin{tabular}{|l}
5.5 .1 \\
5.5 .2 \\
5.5 .3 \\
5.5 .4
\end{tabular}} & \multirow{5}{*}{\begin{tabular}{|l|} 
Population Monitoring \\
Aerial Surveys \\
Banding \\
Lake Productivity Data Compilation
\end{tabular}} & \multirow{5}{*}{$\begin{array}{l}\text { SRD/ACA } \\
\text { SRD } \\
\text { SRD/ACA } \\
\text { SRD/ACA }\end{array}$} & 28 & 28 & 28 & 84 \\
\hline & & & 3.5 & 3.5 & 3.5 & 10.5 \\
\hline & & & $*$ & $*$ & $*$ & 0 \\
\hline & & & 4 & & & 4 \\
\hline & & & 35.5 & 31.5 & 31.5 & 98.5 \\
\hline 5.6 & Resourcing & & & & & \\
\hline \multirow[t]{3}{*}{$5.6 .1-5.6 .2$} & \multirow[t]{2}{*}{ Funding Securement } & \multirow[t]{2}{*}{ SRD } & 5 & 5 & 5 & 15 \\
\hline & & & 5 & 5 & 5 & 15 \\
\hline & Total & & 222.5 & 185 & 178.5 & 586 \\
\hline
\end{tabular}

' all costs of coordination are 'in-kind' contributions of recovery team members and their organizations

* costs included in other activities 


\subsection{REFERENCES}

Alberta Fish and Wildlife. 1991. Management plan for the piping plover in Alberta (final draft). Alberta Fish and Wildlife, Edmonton, AB. 67 pp.

Bjorge, R. R. 1997. The 1996 piping plover census in Alberta. Pp. 158-163 In 1996 International piping plover census (J. H. Plissner and S.M. Haig, eds.). Report to U.S. Geological Survey, Biological Resources Division, Forest and Rangeland Ecosystem Science Center, Corvallis, Oregon. 231 pp.

Bjorge, R. R., and A. J. Murphy. In prep. The 1996 piping plover census in Alberta. Unpublished report, Alberta Natural Resources Service, Parkland Region, Red Deer, AB. $37 \mathrm{pp}$.

Bottitta, G. E., A. M. Cole, and B. Lapin. 1997. Piping plovers produce two broods. Wilson Bulletin 109:337-339.

Cairns, W. E. 1982. Biology and behavior of breeding piping plovers. Wilson Bulletin 94:531545.

Canadian Permanent Committee on Geographic Names. 1988. Gazetteer of Canada: Alberta, $3^{\text {rd }}$ edition. Department of Energy, Mines and Resources, Ottawa, ON. 64 pp.

COSEWIC. 2001. Canadian species at risk, May 2001. Committee on the Status of Endangered Wildlife in Canada, Ottawa, ON. 38 pp.

Espie, R. H. M., R. M. Brigham, and P. C. James. 1992. Breeding ecology of the piping plover at Lake Diefenbaker, Saskatchewan. Unpublished report for Canadian Wildlife Service, Edmonton, AB. 31 pp.

Flemming, S. P., R. D. Chiasson, P. C. Smith, P. J. Austin-Smith, and R. P. Bancroft. 1988. Piping plover in Nova Scotia related to its reproductive and behavioural responses to human disturbance. Journal of Field Ornithology 59: 321-330.

Goossen, J. P. 1989. Prairie piping plover conservation: first annual report (1988). Unpublished report, Canadian Wildlife Service, Edmonton, AB. 19 pp.

Goossen, J. P. 1994. Prairie piping plover conservation: 1992 and 1993. Unpublished draft report, Canadian Wildlife Service, Edmonton, AB. 34 pp.

Goossen, J. P., D. L. Amirault, S. Richard, R. Bjorge, J. Brazil, S. Brechtel, R. Chiasson, G. N. Corbett, F. R. Curley, M. Elderkin, S. P. Flemming, W. Harris, L. Heyens, D. Hjertaas, M. Huot, R. Jones, W. Koonz, P. Laporte, R. I. G. Morrison, C. Stewart, L. Swanson and E. Wiltse. 2002. National recovery plan for piping plover (Charadrius melodus). National Recovery Plan No. 22. Recovery of Nationally Endangered Wildlife. Ottawa, ON. 47 pp. 
Goossen, J. P., S. M. Westworth, B. Yee, D. Thorson, and I. Michaud. 2000. Atlas of piping plovers in the Canadian Prairie Provinces and Ontario. Multimedia CD-ROM atlas produced by Environment Canada, Edmonton and Regina.

Haig, S. M. 1985. Updated status report on the piping plover Charadrius melodus in Canada. Committee on the Status of Endangered Wildlife in Canada, Ottawa, ON. 23 pp.

Haig, S. M. 1992. Piping plover. In The Birds of North America, No. 2 (A. Poole, P. Stettenheim and F. Gill, eds.). The Academy of Natural Sciences, Philadelphia, PA, and The American Ornithologists' Union, Washington, D.C. 18 pp.

Haig, S. M., W. Harrison, R. Lock, L. Pfannmuller, E. Pike, M. Ryan, and J. Sidle. 1988. Recovery plan for piping plovers (Charadrius melodus) of the Great Lakes and northern Great Plains. U. S. Fish and Wildlife Service, Twin Cities, MN. 160 pp.

Haig, S. M., and L. W. Oring. 1988a. Mate, site, and territory fidelity in piping plovers. Auk 105:268-277.

Haig, S. M., and L. W. Oring. 1988b. Distribution and dispersal in the piping plover. Auk 105:630-638.

Harris, W. C. 1992. Impact assessment of piping plover breeding habitat on twenty-one lakes in southern Saskatchewan. Unpublished report for Saskatchewan Wetland Conservation Corporation, Regina, SK. 10 pp.

Heckbert, M. D. 1994. Piping plover (Charadrius melodus) ecology and conservation in Alberta (1994): Reflex Lake and Killarney Lake field report. Unpublished report, Alberta Fish and Wildlife Services, Vermilion, AB. 152 pp.

Heckbert, M. D., and K. D. Cantelon. 1996. Piping plover (Charadrius melodus) ecology and conservation in Alberta (1995): east-central Alberta field report. Unpublished report for Natural Resources Service and Alberta NAWMP Centre, Edmonton, AB. 163 pp.

Hofman, D. E. 1992. 1992 piping plover survey, Little Fish Lake, Alberta. Unpublished report, Alberta Fish and Wildlife Division, Red Deer, AB. 16 pp.

Hofman, D. E. 1994. The 1991 piping plover census in Alberta. Pp. 43-47 In The 1991 International Piping Plover Census in Canada (S. P. Flemming, ed.). Canadian Wildlife Service Occasional Paper No. 82. 59 pp.

Jung, T. S., J. P. Goossen, B. Aitken, and I. A. Bisson. 1998. Conservation biology of piping plovers at Lake Diefenbaker, Saskatchewan: 1997 progress report. Unpublished report, Canadian Wildlife Service, Edmonton, AB. 49 pp. + appendices. 
Michaud, I., and D. Prescott. 1999. Use of predator exclosures to protect piping plover nests in Alberta and Saskatchewan: 1999 field season report. Alberta Conservation Association, Edmonton, AB. 9 pp. + appendices.

Murphy, R. K., M. L. Sondreal, D. A. Guenther, and M. P. Nenneman. 1995. Reproductive success of piping plovers on alkali lakes in northwestern North Dakota. Pp. 13-21 In Conservation of piping plovers in northwestern North Dakota. 1995 annual report. 19 pp. + appendices.

Pinel, H. W., W. W. Smith, and C. R. Wershler. 1991. Alberta birds, 1971-1980. Provincial Museum of Alberta, Natural History Occasional Paper No. 13, Edmonton, AB. 243 pp.

Plissner, J. H., and S. M. Haig. 1997. 1996 International Piping Plover Census. U.S. Geological Survey, Biological Resources Division, Forest and Rangeland Ecosystem Science Center, Corvallis, OR. 231 pp.

Plissner, J. H., and S. M. Haig. 2000. Viability of piping plover Charadrius melodus metapopulations. Biological Conservation 92:163-173.

Prescott, D. R. C. 1997. Status of the piping plover (Charadrius melodus) in Alberta. Alberta Environmental Protection, Wildlife Management Division, Wildlife Status Report No. 1, Edmonton, AB. 19 pp.

Prescott, D. R. C. 2001a. Aerial reconnaissance surveys for piping plover habitat in east-central Alberta, May 2001. Alberta Sustainable Resource Development, Fish and Wildlife Division, Alberta Species at Risk Report No. 26, Edmonton, AB. 10 pp.

Prescott, D. R. C. 2001b. The 2001 International Piping Plover Census in Alberta. Alberta Sustainable Resource Development, Fish and Wildlife Division, Alberta Species at Risk Report No. 27, Edmonton, AB. 15 pp.

Prindiville Gaines, E., and M. R. Ryan. 1988. Piping plover habitat use and reproductive success in North Dakota. Journal of Wildlife Management 52:266-273.

Richardson, I. M. 1999. Predator exclosures: a management technique to increase piping plover (Charadrius melodus) reproductive success in the Canadian prairies. M.Sc. thesis, University of Alberta, Edmonton, AB. 65 pp.

Root, B. G., M. R. Ryan, and P. M. Mayer. 1992. Piping plover survival in the Great Plains. Journal of Field Ornithology 63:10-15.

Ryan, M. R., B. G. Root, and P. M. Mayer. 1993. Status of piping plovers in the Great Plains of North America: a demographic simulation model. Conservation Biology 7:581-585.

Wershler, C. R. 1992. An analysis of piping plover management concerns in Alberta. Unpublished report for Alberta NAWMP Centre, Edmonton, AB. 56 pp. 
Wershler, C., and C. Wallis. 1987. Status of the piping plover in Alberta, 1986. Unpublished report for World Wildlife Fund Canada and Canadian Wildlife Service, Calgary, AB. 54 pp.

Weseloh, D. V., and L. M. Weseloh. 1983. Numbers and nest site characteristics of the piping plover in central Alberta, 1974-1977. Blue Jay 41:155-161.

Whyte, A. J. 1985. Breeding biology of the piping plover (Charadrius melodus) in central Saskatchewan. M.Sc. thesis, University of Saskatchewan, Saskatoon, SK. 53 pp. 


\subsection{APPENDICES}

Appendix 1. Lakes known to have supported piping plovers in Alberta. Population sizes are listed for each of the four major surveys conducted in Alberta, although birds on some lakes were reported only in years other than those listed. See Appendix 2 for a map of lake locations. Sources: Wershler and Wallis (1986), Hofman (1994), Bjorge (1997), Prescott (1997), Goossen et al. (2000) and Prescott (2001b).

\begin{tabular}{|c|c|c|c|c|c|c|c|c|c|}
\hline \multirow[b]{2}{*}{$\begin{array}{c}\text { Map } \\
\#\end{array}$} & \multirow[b]{2}{*}{ Lake } & \multirow[b]{2}{*}{$\begin{array}{l}\text { Breeding } \\
\text { Status }\end{array}$} & \multicolumn{4}{|c|}{ Total \# of Birds } & \multirow[b]{2}{*}{$\begin{array}{c}\text { Threats }^{2} \text { in } \\
2001\end{array}$} & \multirow[b]{2}{*}{$\begin{array}{l}\text { Latitude } \\
\left({ }^{\circ} \mathrm{N}\right)\end{array}$} & \multirow[b]{2}{*}{$\begin{array}{l}\text { Longitude } \\
\left({ }^{\circ} \mathrm{W}\right)\end{array}$} \\
\hline & & & 1986 & 1991 & 1996 & 2001 & & & \\
\hline 1 & Akasu & $\mathrm{B}$ & & & 10 & 2 & $\mathrm{C}, \mathrm{V}$ & 53.50 & 111.02 \\
\hline 2 & Albert & B & & & 2 & 6 & $\mathrm{C}$ & 53.17 & 110.45 \\
\hline 3 & Baxter & B & 0 & 2 & 2 & 6 & $\mathrm{C}, \mathrm{P}, \mathrm{V}$ & 52.94 & 110.73 \\
\hline 4 & Beaverhill & B & 0 & & 13 & 0 & C & 53.45 & 112.53 \\
\hline 5 & Birch & B & & & 19 & 7 & $\mathrm{C}, \mathrm{M}, \mathrm{V}$ & 53.32 & 111.59 \\
\hline 6 & Bittern & B & 0 & & 2 & 0 & $\mathrm{C}, \mathrm{M}, \mathrm{V}$ & 53.05 & 113.08 \\
\hline 7 & Bow R./Carseland & ? & & & & & N/S & 50.83 & 113.43 \\
\hline 8 & Buffalo & B & 2 & 0 & 0 & 0 & $\mathrm{R}, \mathrm{V}$ & 52.45 & 112.90 \\
\hline 9 & Chain “\#1" (Pearl) & B & 0 & 2 & 0 & 4 & $\mathrm{~V}$ & 51.77 & 112.10 \\
\hline 10 & Chain “\#3” (Clear) & B & 1 & 2 & 0 & 0 & & 51.79 & 112.13 \\
\hline 11 & Chain “\#4” & B & 12 & 5 & 13 & 5 & C & 51.80 & 112.15 \\
\hline 12 & Chain "\#6" & B & 1 & 2 & 0 & 0 & $\mathrm{~V}$ & 51.84 & 112.18 \\
\hline 13 & Chappice & $\mathrm{B}$ & 17 & 2 & 1 & 0 & $\mathrm{C}, \mathrm{V}$ & 50.15 & 110.35 \\
\hline 14 & Chestermere & NBS & & & 0 & 0 & $\mathrm{R}$ & 51.03 & 113.82 \\
\hline 15 & Cipher & B & 4 & 4 & 4 & 0 & $\mathrm{~V}$ & 52.68 & 110.10 \\
\hline 16 & Cochrane & NBS & & & 0 & 0 & $\mathrm{R}, \mathrm{V}$ & 51.25 & 114.48 \\
\hline 17 & Dalemead & $?$ & & & & & $\mathrm{~N} / \mathrm{S}$ & 50.92 & 113.62 \\
\hline 18 & Dawson & $?$ & & & & & $\mathrm{~N} / \mathrm{S}$ & 51.13 & 113.40 \\
\hline 19 & Dillberry & BS & 0 & & 0 & 0 & & 52.58 & 110.00 \\
\hline 20 & Dowling & B & 18 & 21 & 54 & 4 & $\mathrm{C}, \mathrm{V}$ & 51.73 & 112.01 \\
\hline 21 & Eagle & BS & 0 & & 0 & 0 & & 51.00 & 113.32 \\
\hline 22 & "Foster" & B & 6 & & 2 & 4 & $\mathrm{C}, \mathrm{M}, \mathrm{V}$ & 52.23 & 110.55 \\
\hline 23 & Frank & B & 0 & & 0 & 0 & & 50.57 & 113.72 \\
\hline 24 & Frog & BS & & & & 3 & $\mathrm{C}, \mathrm{M}, \mathrm{R}$ & 53.92 & 110.33 \\
\hline 25 & Gillespie & BS & 0 & 0 & 0 & 0 & & 52.42 & 110.18 \\
\hline 26 & Gooseberry & B & 4 & 9 & 0 & 0 & $\mathrm{C}, \mathrm{V}$ & 52.12 & 110.73 \\
\hline 27 & Goosequill & B & 2 & 0 & 0 & 0 & & 52.05 & 113.15 \\
\hline 28 & "Greenlee" & B & 3 & 4 & 2 & 0 & $\mathrm{C}, \mathrm{P}$ & 52.22 & 110.48 \\
\hline 29 & Gull & B & 0 & & 0 & 0 & & 52.57 & 114.00 \\
\hline 30 & Handhills & B & 37 & 20 & 54 & 9 & $\mathrm{C}, \mathrm{V}$ & 51.49 & 112.12 \\
\hline 31 & Hansman & B & 0 & & & 6 & $\mathrm{M}, \mathrm{P}, \mathrm{V}$ & 52.39 & 110.39 \\
\hline 32 & Hattie & NBS & 0 & & 0 & 0 & C & 52.98 & 111.57 \\
\hline 33 & Horseshoe & B & 2 & 0 & 6 & 0 & $\mathrm{C}, \mathrm{I}$ & 52.36 & 110.74 \\
\hline 34 & "Janet" & BS & & & 0 & 0 & $\mathrm{C}$ & 51.02 & 113.87 \\
\hline 35 & "Junction" & B & & & 2 & 0 & & 53.45 & 111.75 \\
\hline 36 & Keho & B & & 3 & 1 & 0 & $\mathrm{~V}, \mathrm{~W}$ & 49.95 & 112.98 \\
\hline 37 & Killarney & B & 0 & 22 & 23 & 2 & V & 52.58 & 110.10 \\
\hline
\end{tabular}




\begin{tabular}{|c|c|c|c|c|c|c|c|c|c|}
\hline \multirow{2}{*}{$\underset{\#}{\text { Map }}$} & \multirow[b]{2}{*}{ Lake } & \multirow{2}{*}{$\begin{array}{l}\text { Breeding } \\
\text { Status }\end{array}$} & \multicolumn{4}{|c|}{ Total \# of Birds } & \multirow{2}{*}{$\begin{array}{l}\text { Threats }^{2} \\
\text { in } 2001\end{array}$} & \multirow{2}{*}{$\begin{array}{c}\text { Latitude } \\
\left({ }^{\circ} \mathrm{N}\right)\end{array}$} & \multirow{2}{*}{$\begin{array}{c}\text { Longitude } \\
\left({ }^{\circ} \mathrm{W}\right)\end{array}$} \\
\hline & & & 1986 & 1991 & 1996 & 2001 & & & \\
\hline 38 & Leane & $\mathrm{B}$ & 0 & 2 & 1 & 2 & & 52.56 & 110.07 \\
\hline 39 & Lesser Slave & BS & & & & & $\mathrm{N} / \mathrm{S}$ & 55.45 & 115.45 \\
\hline 40 & Little Fish & $\mathrm{B}$ & 23 & 19 & 0 & 3 & $\mathrm{M}, \mathrm{R}, \mathrm{V}$ & 51.37 & 112.22 \\
\hline 41 & Long & BS & 1 & & 0 & 0 & & 51.22 & 113.422 \\
\hline 42 & Lowden & $?$ & 0 & 0 & 0 & 0 & $\mathrm{~V}$ & 52.15 & 112.70 \\
\hline 43 & McDonald & BS & 0 & 0 & 0 & 0 & I & 51.20 & 113.94 \\
\hline 44 & McGregor & BS & & & 0 & 0 & $\mathrm{C}, \mathrm{R}, \mathrm{W}$ & 50.42 & 112.87 \\
\hline 45 & "Metiskow" & $\mathrm{B}$ & & 2 & 2 & 0 & $\mathrm{C}$ & 52.40 & 110.63 \\
\hline 46 & Miquelon "\#1" & BS & & & 1 & 0 & $\mathrm{~V}$ & 53.21 & 112.83 \\
\hline 47 & Miquelon “\#2” & $\mathrm{B}$ & 0 & 0 & 0 & 0 & $\mathrm{~V}$ & 53.28 & 112.84 \\
\hline 48 & Miquelon “\#3" & B & & 0 & 0 & 0 & $\mathrm{C}, \mathrm{V}$ & 53.26 & 112.92 \\
\hline 49 & Muriel & $\mathrm{B}$ & & & 17 & 19 & $\mathrm{M}, \mathrm{R}$ & 54.13 & 110.70 \\
\hline 50 & Namaka & BS & 0 & & 0 & 0 & & 50.93 & 113.22 \\
\hline 51 & "Neutral Hills A" & B & 12 & 2 & 0 & 0 & $\mathrm{C}$ & 52.06 & 110.93 \\
\hline 52 & "Neutral Hills B1" & B & 4 & 0 & 2 & 0 & $\mathrm{C}, \mathrm{P}, \mathrm{V}$ & 52.09 & 110.94 \\
\hline 53 & "Neutral Hills B2" & BS & 0 & 0 & 0 & 0 & $\mathrm{C}$ & 52.10 & 110.97 \\
\hline 54 & "Neutral Hills C1" & BS & 6 & 5 & 5 & 0 & $\mathrm{C}, \mathrm{M}$ & 52.13 & 110.93 \\
\hline 55 & "Neutral Hills C2" & BS & & & & & $\mathrm{N} / \mathrm{S}$ & 52.13 & 110.97 \\
\hline 56 & Newell & BS & $3+$ & 1 & 0 & 0 & & 50.43 & 111.92 \\
\hline 57 & Oliver & $\mathrm{B}$ & 0 & & 0 & 0 & $\mathrm{~N} / \mathrm{S}$ & 53.28 & 113.02 \\
\hline 58 & "Piper" & B & $15+$ & 12 & 6 & 2 & $\mathrm{C}$ & 52.33 & 110.63 \\
\hline 59 & Plain & $\mathrm{B}$ & & & & 13 & V & 53.61 & 111.70 \\
\hline 60 & Plover & BS & 0 & & 0 & 6 & $\mathrm{C}$ & 51.48 & 111.38 \\
\hline 61 & Red Deer & BS & 0 & & 2 & 3 & $\mathrm{C}, \mathrm{M}, \mathrm{R}, \mathrm{V}, \mathrm{W}$ & 52.70 & 113.05 \\
\hline 62 & Reesor & $?$ & & & 0 & 0 & & 49.67 & 110.10 \\
\hline 63 & "Rider" & B & 15 & 7 & 0 & 0 & $\mathrm{M}, \mathrm{V}, \mathrm{W}$ & 52.52 & 112.77 \\
\hline 64 & Rockeling Bay & B & 18 & 6 & 0 & 0 & $\mathrm{M}, \mathrm{W}$ & 52.57 & 112.82 \\
\hline 65 & Sam & B & $6+$ & 4 & 2 & 0 & $\mathrm{C}, \mathrm{V}$ & 50.15 & 110.25 \\
\hline 66 & Sounding & B & 18 & 0 & 2 & 0 & $\mathrm{~N} / \mathrm{S}$ & 52.13 & 110.48 \\
\hline 67 & Spiers & $\mathrm{B}$ & 6 & 2 & 0 & 0 & V & 51.92 & 112.23 \\
\hline 68 & St. Mary Reservoir & BS & & & 3 & 2 & $\mathrm{C}, \mathrm{R}, \mathrm{W}$ & 49.33 & 113.18 \\
\hline 69 & Stirling & BS & & & & & $\mathrm{N} / \mathrm{S}$ & 49.53 & 112.58 \\
\hline 70 & Sunken & B & $5+$ & 8 & 7 & 6 & $\mathrm{C}$ & 52.38 & 110.65 \\
\hline 71 & Unnamed & BS & & & & & $\mathrm{N} / \mathrm{S}$ & 51.23 & 113.58 \\
\hline 72 & Unnamed & BS & & & & & $\mathrm{N} / \mathrm{S}$ & 51.50 & 114.60 \\
\hline 73 & Unnamed & B & & & 2 & 0 & $\mathrm{C}$ & 52.60 & 110.12 \\
\hline 74 & Unnamed & NBS & & & & & $\mathrm{N} / \mathrm{S}$ & 50.96 & 113.85 \\
\hline 75 & Unnamed & B & & & & 5 & $\mathrm{C}, \mathrm{P}$ & 52.29 & 110.68 \\
\hline 76 & Unnamed & BS & 1 & 0 & 0 & 0 & $\mathrm{C}$ & 50.13 & 110.25 \\
\hline 77 & "West" Reflex & $\mathrm{B}$ & $46+$ & 12 & 19 & 31 & $\mathrm{C}, \mathrm{M}, \mathrm{R}$ & 52.67 & 110.00 \\
\hline 78 & Whitewater & NBS & & & 0 & 0 & & 52.87 & 111.78 \\
\hline 79 & Whitford & BS & & & & & $\mathrm{N} / \mathrm{S}$ & 53.87 & 112.25 \\
\hline
\end{tabular}

${ }^{\mathrm{I}} \mathrm{B}=$ Breeding confirmed, BS=Breeding season (May 15-July 31 ) without breeding confirmation, NBS=Nonbreeding season.

${ }^{2} \mathrm{C}=$ Cattle trampling, $\mathrm{I}=$ Industrial activity (other than petroleum), $\mathrm{M}=$ Motorized vehicles, $\mathrm{P}=$ Petroleum exploration and/or extraction, $\mathrm{R}=$ Recreational or residential development, $\mathrm{V}=$ Vegetation encroachment, $\mathrm{W}=\mathrm{W}$ ater management. $\mathrm{N} / \mathrm{S}=\mathrm{Not}$ surveyed in 2001. 
Appendix 2. Map of lakes where piping plovers have been reported in Alberta. See Appendix 1 for specific lake details.

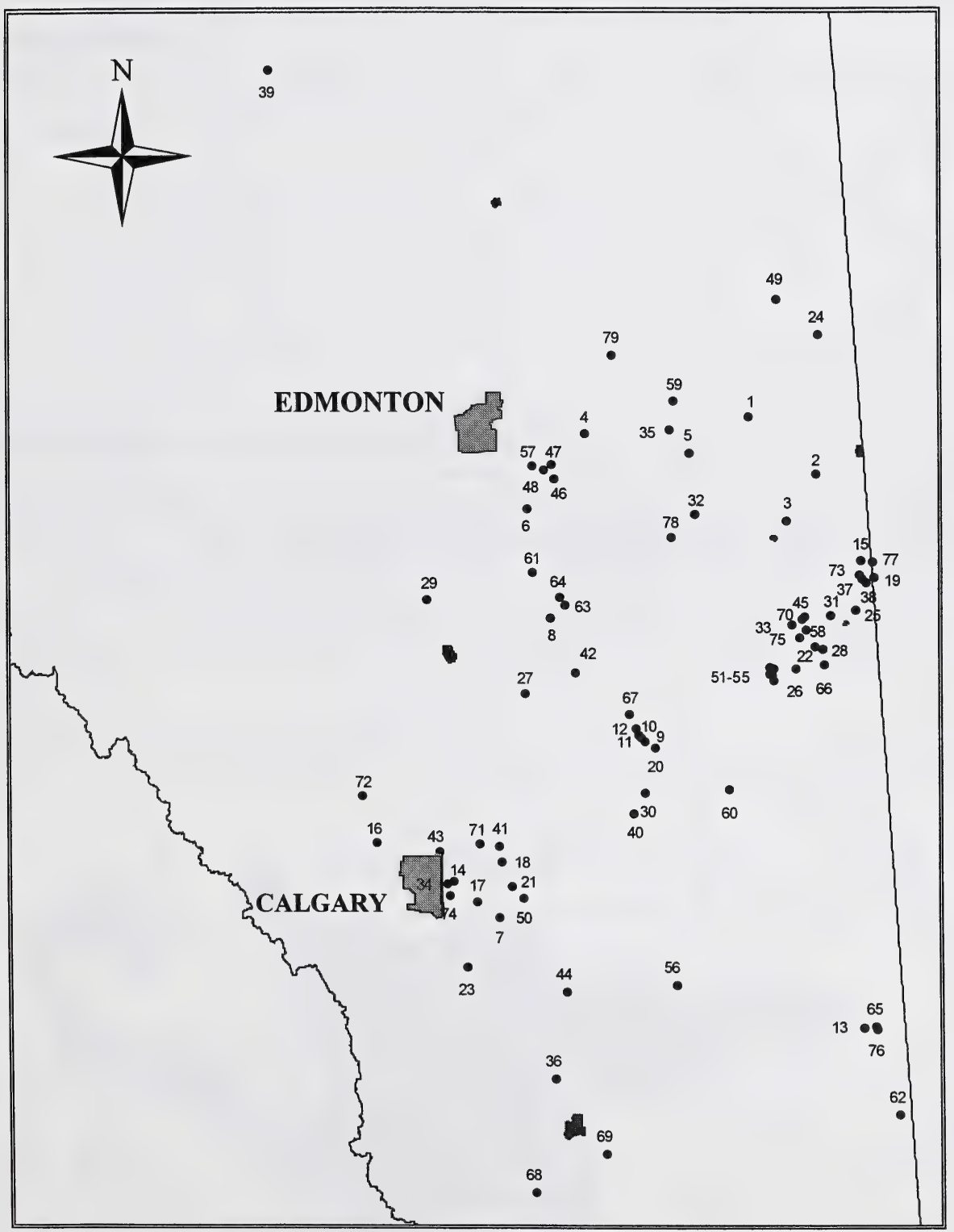


Appendix 3. Example of a lake management plan that will be prepared for all key piping plover lakes in Alberta (see section 5.2.4). This example is fictitious, but is presented to show realistic management scenarios on a typical piping plover lake in Alberta. The specific format and content of the plans may change as the project develops. 


\section{Fake Lake Management Plan}

\section{Location}

Fake Lake is located approximately $9 \mathrm{~km}$ northeast of the town of Nowhere, in the northeast corner of Fake Lake County. The approximate lake centre is at $57^{\circ} 53^{\prime} \mathrm{N}, 135^{\circ} 43^{\prime} \mathrm{W}$. The lake is located in the Northern Fescue Subregion of the Grassland Natural Region. Mapsheet: 93 D/15.

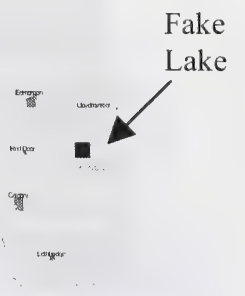

\section{Physical Description}

This run-off fed, saline lake has a surface area of $22 \mathrm{~km}^{2}$. Mudflats and beaches of sand and gravel provide suitable piping plover habitat on all four peninsulas (one spanning SW and SE 01, another in SE 06 and the remaining two in NE 36) and in the southeast corner of the southern bay. New nesting habitat is beginning to appear as water levels drop (Jones 1998). The most promising of these areas is an extension of the peninsula in SE and SW of section 06. Fake Lake County is a diverse region encompassing areas of residential, commercial, industrial, and resort development, with the predominant land use being agriculture. The lands immediately surrounding Fake Lake are primarily native pasture that supports cattle grazing. The exception to this is the lands surrounding the southern bay, which are utilised primarily for crops. In most areas, grazing or agricultural land uses are present right up to the lakeshore; only the large peninsula in the northwest corner of the lake contains significant aspen groves. Water levels in 2001 were down significantly from 1996. As a result, the peninsula in SE 06 has grown while the west arm of the lake has retreated to the NW corner of SW 01. There is no public access to the lake and its salinity prevents it from supporting a fishery.

\section{History of Plover Use}

At least nine complete surveys of Fake Lake have been conducted since 1979. Birds have been recorded in all years except 1982, and have numbered as high as 12 adults (2001). Piping plovers have been observed in four different quarter sections on Fake Lake, with confirmed breeding occurring in three different quarters (see Table 1). Due to the lake's isolation from other plover supporting lakes in the province, detailed nest success data have only been collected during 2001 and little is known about fledging productivity.

Figure 1. Map of known plover habitat on Fake Lake.

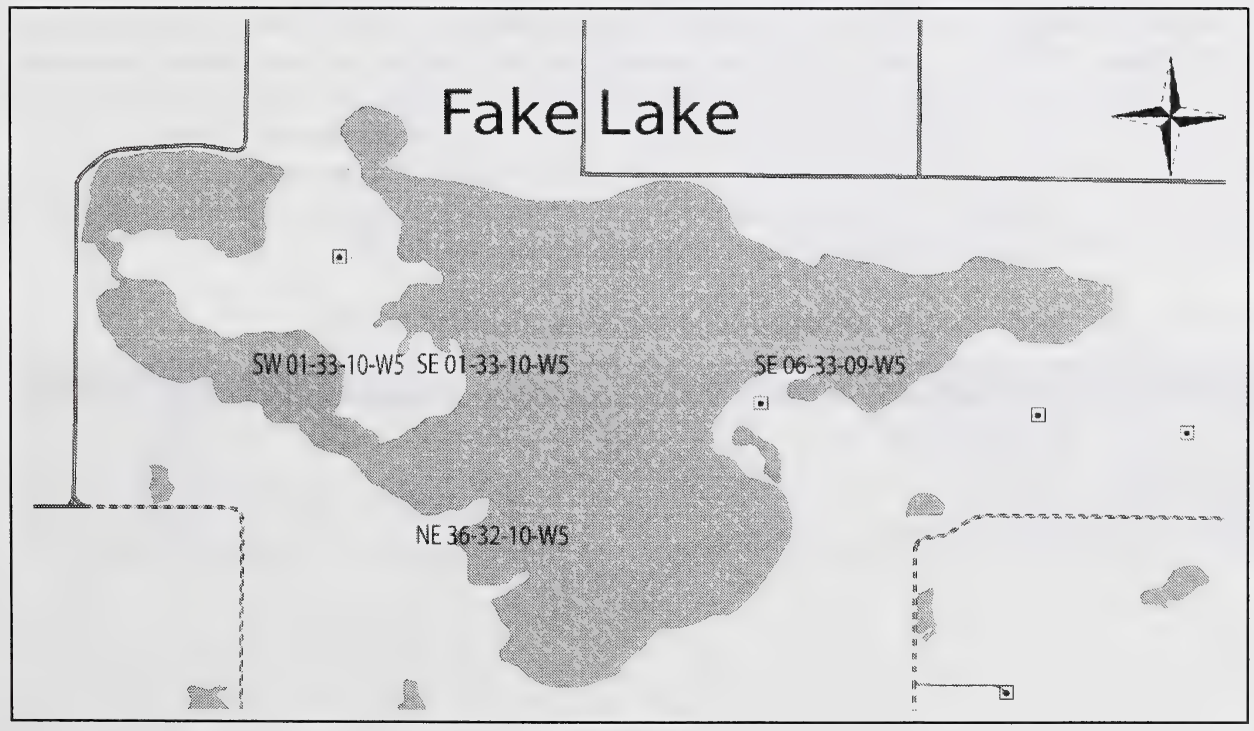


Table 1. Known piping plover use of Fake Lake area.

\begin{tabular}{|l|c|c|c|c|c|c|c|c|c|}
\hline Fake Lake & 1979 & 1982 & 1986 & 1991 & 1995 & 1996 & 1999 & 2000 & 2001 \\
\hline \hline SW 01-33-10-W5 & & & & 0 & $2 \mathrm{~A}$ & $1 \mathrm{~A}$ & $1 \mathrm{~A}$ & $2 \mathrm{~A} 1 \mathrm{~N}$ & $1 \mathrm{~A}$ \\
\hline SE 01-33-10-W5 & & & & 0 & 0 & 0 & $5 \mathrm{~A}$ & $4 \mathrm{~A} 2 \mathrm{~N}$ & $6 \mathrm{~A} 3 \mathrm{~N}$ \\
\hline SE 06-33-09-W5 & & & $1 \mathrm{~A}$ & $2 \mathrm{~A}$ & $2 \mathrm{~A}$ & $2 \mathrm{~A}$ & $5 \mathrm{~A} 1 \mathrm{~N}$ & $2 \mathrm{~A} 1 \mathrm{~N}$ & $5 \mathrm{~A} 2 \mathrm{~N}$ \\
\hline NE 36-32-10-W5 & & & & $1 \mathrm{~A}$ & & 0 & 0 & 0 & 0 \\
\hline Total & $\mathbf{2}$ & $\mathbf{0}$ & $\mathbf{1}$ & $\mathbf{3}$ & $\mathbf{4}$ & $\mathbf{3}$ & $\mathbf{1 1}$ & $\mathbf{8}$ & 12 \\
\hline Reference & 1,2 & 2 & 3 & 4 & 5 & 6 & 7 & 7 & 8 \\
\hline
\end{tabular}

Salt and Wilk $1958^{1}$, Wershler and Wallis $1987^{2}$, Wershler $1990^{3}$, Hofman $1994^{4}$, Bjorge unpub. AEP data $^{5}$, Bjorge $1997^{6}$, Moore pers. comm. ${ }^{7}$, Prescott $2001^{8}$.

\section{Previous Management Activities and Designations}

Management activity on Fake Lake has been limited to the erection of predator nest exclosures during the summer of 2001. Over the years, the lake has also received several noteworthy designations. In 1995, Fake Lake was identified as a potential Western Hemisphere Shorebird Reserve Network site because of its regional importance to shorebirds (Smith 1995). It has also been identified as an Important Bird Area site (Yupp 2000).

\section{Threats and Management Priorities}

Threats to the lake include cattle grazing in all three quarter sections where breeding has been documented. During the summer of 2001, when predator nest exclosures were used, the only nest failure to occur was attributed to cattle trampling. Additionally, oil extraction by two companies has resulted in the erection of five pump jacks within the last two years. All of these wells are within $600 \mathrm{~m}$ of Fake Lake, and the one in SE 06 is within $50 \mathrm{~m}$. Other potential threats include nests of avian predators (i.e. crows, merlins, etc.) in the aspen stands on the northwest peninsula and, although no gull colony has been observed, at least 100 ring-billed and California gulls (potential nest predators) used the lake for feeding on a regular basis in 2001 .

Table 2 details land ownership, threats and management urgency as of 2001. Management urgency is rated as high, medium or low, based on observed threats, ownership and plover use of a particular quarter. SE and SW of 01 are rated as high urgency because of the intense grazing they experience and their demonstrated importance over the years as prime breeding habitat. The fact that they are owned by the same individual will likely make cooperative management negotiations and landowner communication simpler. SE 06 received a medium rating because, although oil extraction occurs in close proximity to the plover habitat, activity is minimal and doesn't occur directly on breeding habitat. Cattle grazing is an issue; however, in the past this area has been grazed lightly and public ownership means that the resolution of any future problems can be dealt with rather swiftly. Management urgency of NE 36 is low due to the lack of any significant threats and its occasional use by plovers.

Table 2. Ownership, threats and management urgency as identified in 2001.

\begin{tabular}{|l|l|l|c|}
\hline Fake Lake & Ownership & Threats & Management Urgency \\
\hline \hline SW 01-33-10-W5 & P (R. Jones) & Cattle Grazing & High \\
\hline SE 01-33-10-W5 & P (R. Jones) & Cattle Grazing & High \\
\hline SE 06-33-09-W5 & Crown & Oil Extraction, Cattle Grazing & Medium \\
\hline NE 36-32-10-W5 & P (B. Roberts) & & Low \\
\hline
\end{tabular}




\section{Recovery Actions and Costs}

Table 3. Recovery actions suggested for managing piping plovers on Fake Lake, and associated costs $(\$ 1000 \mathrm{~s})$.

\begin{tabular}{|c|c|c|c|c|}
\hline $\begin{array}{l}\text { Task } \\
\text { No. }\end{array}$ & Activity & Prionity & Lead Agency & $\begin{array}{c}\text { Cost } \\
2002-04\end{array}$ \\
\hline 1 & Fake Lake Management & & & \\
\hline 1.1 & $\begin{array}{l}\text { Liase with R. Jones to establish a grazing agreement, lease or purchase of SW and SE 01- } \\
\text { 33-10-W5 (32 acres). }\end{array}$ & High & SRD & 8 \\
\hline 1.2 & $\begin{array}{l}\text { Erect approximately } 0.5 \text { miles of fence along shore of SW and SE } 01-33-10-W 5 \text { to } \\
\text { control cattle access to plover habitat. }\end{array}$ & High & SRD & 2.8 \\
\hline 1.3 & $\begin{array}{l}\text { Manage crown land (SE 06-33-09-W5) for piping plovers by removing cattle during the } \\
\text { breeding season (May 15-July 31). }\end{array}$ & Medium & SRD & $*$ \\
\hline 1.4 & $\begin{array}{l}\text { Liase with B. Roberts (NE 36-32-10-W5) and oil executives to discuss plover initiatives } \\
\text { occurring on the lake and the importance of the lake for plover breeding. }\end{array}$ & Medium & SRD & * \\
\hline 1.5 & $\begin{array}{l}\text { Place protective notation on the following quarters: SW and SE 01-33-10-W5, SE 06-33- } \\
09-\mathrm{W} 5 \text { and NE 36-32-10-W5. }\end{array}$ & High & SRD & 0.5 \\
\hline 1.6 & $\begin{array}{l}\text { Remove stick nests during the winter, to dissuade avian predators from nesting near } \\
\text { important plover breeding habitat. }\end{array}$ & Low & $\mathrm{ACA}$ & * \\
\hline 1.7 & Erect predator nest exclosures over all nests. & Medium & ACA & * \\
\hline 1.8 & $\begin{array}{l}\text { Conduct population monitoring to obtain improved productivity data, in the form of adult } \\
\text { and brood surveys. }\end{array}$ & High & $\mathrm{ACA}$ & $*$ \\
\hline & \multicolumn{3}{|l|}{ Total } & 11.3 \\
\hline
\end{tabular}

* These activities are province-wide, thus costs are detailed in provincial activity budget.

\section{References}

Will be made available for actual lake management plans. 


\section{List of Titles in This Series}

(as of September 2002)

No. 1 Maintenance and recovery plan for western blue flag (Iris missouriensis) in Canada. (2002)

No. 2 Alberta piping plover recovery plan 2002-2004. (2002) 

NATIONAL LIBRARY OF CANADA
Bibliothèque nationale du Canada
||

|||||||||||||||||||||||||||||||||||||||||||||||||||||||||||||||||||||||||||||||||||||||||||

33286528659697 